\title{
Service provision in a globalised world
}

\author{
Rosina Márquez Reiter and Luisa Martín Rojo
}

This issue brings together a collection of essays on the most prevalent approaches to the analysis of linguistic practices in institutional contexts in the light of the social and communicative changes that have taken place in late modernity. The articles explore institutional discourse in public and private institutions with special attention to the provision of services in relatively new and developing multicultural contexts. From their different analytic perspectives and institutional environments, the analyses illustrate how communicative practices have been modified in order to adapt to the new ways in which capitals, production, management, the markets, the labour force, information and technology are organised in this global era via flows which cut across national borders.

Institutional discourse in general, and the discourse of service encounters in private, public and public-private sites in particular has received a great deal of attention in recent years (see, for example, Arminen 2005; Collins and Slembrouck 2005; Dûchene and Heller forthcoming; McHoul and Rapley 2001; Rampton 2007; Risager 2006). Recently, Spain has experienced an influx in the flow of immigration from non-Spanish speaking countries, and therefore of speakers of languages other than Spanish (from 1997-2006, Instituto Nacional de Estadística). This has created a new multicultural reality, and as a result, there has been a burgeoning interest in the various discursive ramifications of this new multiculturalism in Spain (see, for example, Carmona 2007; Milans and Martín Rojo 2007; Moyer and Martín Rojo 2007; Valero Garcés 2002; Valero Garcés and Taibi 2004; Codó 2008, for studies on citizen and immigration services). Studies of multicultural interactions have examined not only how different values are granted to official languages in the Spanish state (Spanish Catalan, etc.) and to the lingua franca par excellence (i.e. English), but also how varieties of Spanish are differently valued. More recently, attention has been given to the emergence of linguistic practices in new communicative contexts resulting from globalisation (e.g. intercultural communication in call centres as examined by Marquez Reiter 2009).

Despite the increasing interest in institutional discourse, the significance of the results and methodologies deployed have not yet found a forum where they can be discussed and future directions explored. The aim of this collection is therefore to bring together some of the most prominent voices in this area to review extant research, present new findings and discuss new disciplinary horizons. The studies in this special issue employ a broad sociodiscursive perspective which includes sequential, sociopragmatic and critical discursive analyses as well as a combination of these, in order to investigate linguistic practices in rich multicultural settings, how they shape and are shaped by current socioeconomic and cultural changes. They all examine how linguistic resources and practices are managed, valued, legitimised and actually create the new communicative contexts in which they are immersed (Blommaert 2005; Blommaert, Collins and Slembrouck 2005a; Heller 2004, 2007).

The themes explored in these essays are of a generic kind. They deal with differences in social and pragmatic practices, the complexity of inferential processes with respect to 
the needs and competence of its users, the relationship between service providers and clients, social categorisation and the construction of stereotypes as well as the ideologies which underlie the observed communicative practices of both institutional representatives and clients. However, in each case they are realised specifically with regard to a given setting and to the conversational participants' particular business.

The communicative contexts examined are of particular interest as they offer us a synchronic picture of institutional communication at a time when the societies to which those institutions belong are becoming more diverse and multilingual. As Gumperz (1994: xiii) notes 'people who grew up in distant parts of the world under historically quite distinct circumstances must now work together as part of the same labour force, jointly participate in local community affairs and compete for access to public facilities'. That is, regardless of whether we live abroad or in our own familiar home environment, we are more and more likely to come into direct contact with others who do not share our basic assumptions and perspectives. The articles collected here focus on the contact between different languages within one nation state (i.e. Spain) as well as on the contact between different varieties of the same broad language (i.e. varieties of Spanish). The panorama opened by this issue allows us to reach a deep understanding of the increasing multilingualism in service provision in national and transnational settings. Within this context current linguistic phenomena can be addressed, in particular, the tensions between the pervasive perception of linguistic homogeneity, and participants' multilingual practices, and also the increasing processes of commodification of languages (Spanish and English, in this case). Furthermore, the analysis of data from multilingual Spain, and Latin America, reveals how the value assigned to linguistic resources varies according to the environment, including the setting and its participants, and domain of use, and how within the interactional processes, participants can change and negotiate these values.

The analyses show differences in the framing of public, private or public-private service-providers which affects interactional dynamics and how participants understand the purpose of the exchange and the role they play in it. Owing to their nature, public v. private sector encounters they provide us with an opportunity to see the extent to which some of the analytic perspectives and tools of analysis employed to study discourse in public and private institutions are helpful in examining how discourse is managed in other environments. This will help us to better understand the dynamic nature of institutional interactions in contemporary multicultural settings where communication between institutional representatives and clients is increasingly mediated by the use of computers and telephone lines and; importantly, where old and new power asymmetries are being (re)created.

From their different analytic perspectives, all the papers contribute to the understanding of the discourse of service encounters and how local discourse practices are interwoven with wider social processes. The essays thus offer a window into the complexity of the new configurations of the current sociolinguistic and communicative orders by revealing the production of linguistic ideologies and linguistic norms and the ways in which speakers draw on linguistic resources (forms and practices) when building social differences and power relationships across different institutional contextsmultilingual and multicultural public services and intercultural heterodialectical, private service calls. They focus on the contact between different languages within one nation state (i.e. Spain) as well as on the contact between different varieties of the same broad 
language (i.e. varieties of Spanish). The six papers in this volume are representative of the direction that sociodiscursive studies into institutional discourse have taken and of the settings that have so far been examined. A common denominator across the papers is their concern with the examination of naturally occurring talk from an integrative approach which draws on ethnography, conversation and critical discourse analysis, and interactional sociolinguistics.

The issue begins with Melissa Moyer's paper on the management of multilingualism in public, private and non-governmental institutions in Catalnuya. Moyer provides an indepth discussion of the limitations of how multilingualism is managed by focusing on the languages which are deployed de facto irrespective of those spoken by the participants, in particular those spoken by service-seekers. Along similar lines, Codó and Garrido compare linguistic practices and ideologies in two organisations which service transnational migrants in Barcelona. Despite different social missions and different ideological stances toward migrants, both the free legal advice service and the legal office downplay the role that language plays in the provision of services to their migrant clientele. Both organisations construct multilingualism as exceptional and in so doing espouse a hegemonic stance which in turn leads to exclusion of the very individuals they are meant to serve. Their article points to the need to bring discourse on language and communication to the fore in hiring and training practices in these institutions. Gómez's paper focuses on the structure of a gatekeeping encounter at an asylum application interview. Her analysis reveals the interpreter's accumulation of functions during the interview and how his 'non renditions' lead to an account of the applicant's particular interpretation.

Prego Vázquez discusses how code-switching is used by the employees of a publicprivate water, refuse and sanitation company in Galicia both to exercise power over the clientele while also masking the power asymmetries between them. She shows how the discourse strategies of conversationalisation and motherse, commonly used in professional settings, are in fact realized with code-switching. Márquez Reiter discusses the strategic use of metapragmatic acts in an intercultural mediated service encounter. She shows how speakers of the same broad language (i.e. Spanish) make their differing cultural rules and discursive expectations relevant in their talk.

The five articles are followed by a discussion, by the editors, on current accepted knowledge of institutional discourse in the light of the studies represented in this volume. The editors also discuss the extent to which some of the tools that have been deployed to examine it need revisiting in order to better account for the discursive practices we, as scholars, seek to illuminate.

Further reflections on the issues raised in this special issue are provided by Kristine Fitch's appraisal of the place and role of power in the interactions covered in this issue and Teresa Carbo's 'a view from afar'. Fitch offers an incisive discussion of the similarities and differences in the way power is understood by the contributors to this issue and the claims that can be made on the basis of these interpretations. The issue ends with Carbo's thoughts from afar in which the author builds a bridge between European and Latin American colleagues working in related areas. Carbo offers a fresh comparative perspective on the studies represented in this issue vis á vis relevant ones conducted in Latin America. In doing so, she opens a space for dialogue and disseminates fascinating related work conducted in parallel universes. May the talk continue. 


\section{References}

Arminen, I. (2005) Institutional Interaction. Studies of Talk at Work. Ashgate: England.

Blommaert, J., Collins, J., and Slembrouck, S. (2005a). Polycentricities and interactional regimes in 'globalised' neighbourhoods. Ethnography, 6(2): 205-235.

Blommaert, J., Collins, J., and Slembrouck, S. (2005b) Spaces of multilingualism. Language and Communication 25(3): 197-216.

Blommaert, Jan. (2005) Discourse: A Critical Introduction. Cambridge: Cambridge University Press.

Carmona, J.P. (2007) Análisis discursivo de las prácticas comunicativas de acceso: Los extranjeros en el sistema sanitario. In L. Cortés Rodríguez, A. Bañón, M. Espejo and J.L. Muñío (eds) Discurso y Oralidad (Homenaje al prof. J.J. de Bustos Tovar), vol. 2 663-672. Madrid: Arco / Libros.

Codó, E. (2008) Immigration and Bureaucratic Control. Language Practices in the Public Administration. Berlin: Mouton de Gruyter.

Collins, J. and Slembrouck, S. (2005) Multilingualism and diasporic populations: Spatializing practices, institutional processes and social hierarchies. Language and Communication 25(3): 189-195.

Duchêne, A. and Heller, M. (in progress) Pride and Profit. Language in Late Capitalism. .

Gumperz, J. (1994) Foreword. In W.L. Linda Young Crosstalk and Culture in SinoAmerican communication xiii-xx. Cambridge: Cambridge University Press.

Heller, M. (2004) Globalization and the commodification of languages. In Cabré, M. Teresa; Lorente, Mercè; Solé, Elisabet (eds.) (2004). Lingüística aplicada. Sèrie conferències I seminaris 98-00 77-88. Barcelona: Institut Universitari de Linguistica Aplicada. Barcelona: Universitat Pompeu Fabra.

Heller, M. (2007) Transnational multilingual communities. In: P. Auer and L. Wei (eds) Handbook of Multilingualism. Berlin: Mouton de Gruyter.

Instituto Nacional de Estadística. Spanish Statistical Office. Retrieved on National Immigrant Survey 1997-2007 [(day) month year] from via the Homepage http://www.ine.es/.

Márquez Reiter, R. (2005) Complaint calls to a caregiver service company: The case of desahogo. Intercultural Pragmatics 2(4): 481-513.

Márquez Reiter, R. (2006) Interactional closeness in service calls to Montevidean carer service company. Research on Language and Social Interaction, 39(1): 7-39. 
Márquez Reiter, R. (2008) Intra-cultural variation: Explanations in service calls to two Montevidean service providers. Journal of Politeness Research 4(1): 1-29.

Márquez Reiter, R. (2009) How to get rid of a telemarketing agent: Face-work strategies in a Spanish intercultural service call. In F. Bargiela-Chiappini and M. Haugh (eds) Face, Communication and Social Interaction 55-77. London: Equinox.

Márquez Reiter, R. and Placencia, M.E. (2004) Displaying closeness and respectful distance in Montevidean and Quiteño service encounters. In R. Márquez Reiter and M.E. Placencia (eds) Current Trends in the Pragmatics of Spanish 121-155. Amsterdam/Philadelphia: John Benjamins.

Miguel Pérez Milans, Luisa Martín Rojo (2007) Barreras interaccionales en aulas multilingües: una aproximación crítica a la comunicación intercultural. Cultura, lenguaje y representación /Culture, language and representation: Revista de Estudios Culturales. Castellón: Universitat Jaume I, 4: 203-226.

McHoul, A. and Rapley, M. (eds) (2001) How to Analyse Talk in Institutional Settings: A Casebook of Methods. Continuum: London.

Morales López, E., Prego-Vázquez, G. and Domínguez Seco, L. (2005) Interviews between employees and customers during a company restructuring process. Discourse and Society 16(2): 225-268.

Moyer, M. y Martín Rojo, L. (2007) Migration and citizenship: New Challenges in the regulation of bilingualism. In M. Heller (ed.) Bilingualism. A social approach [pp. 137-160 . Basingstoke: Palgrave.

Orlando, V. (ed.) (2006) Mecanismos Conversacionales en el Español del Uruguay. Análisis de Interacciones Telefónicas de Servicios. Montevideo: Departamento de Publicaciones de la FHCE, Universidad de la República.

Placencia, M.E. (2004) Rapport-building activities in corner shop interactions. Journal of Sociolinguistics 8(2): 215-245.

Placencia, M.E. (2007) Entre lo institucional y lo sociable: Conversación de contacto, identidades y metas múltiples en interacciones en la peluquería. RILI, 1(9): 139-161.

Prego-Vázquez, G. (2007) Frame conflict and social inequality in the workplace: Professional and local discourse struggles in employee/customer interactions. Discourse and Society 18(3): 295-335.

Rampton, B. (2006) Language in late modernity: Interaction in an urban school. Cambridge: Cambridge University Press.

Risager, K. (2006) Language and Culture: Global Flows and Local Complexity. Clevendon: Multilingual Matters. 
Torras, M. and Gafaranga, J. (2002) Social identities and language alternation in nonformal institutional bilingual talk: Trilingual service encounters in Barcelona.

Language in Society 31: 527-548.

Valero Garcés, C. (2002) Análisis conversacional de las interacciones entre proveedores de servicios y usuarios inmigrantes en los centros de salud. Oralia 5: 265-294.

Valero Garcés, C. and Taibi, M. (2004) Análisis de la interacción comunicativa en contextos institucionales entre proveedores de servicios, usuarios e intermediarios lingüísticos. Oralia 7: 173-193. 